\title{
MEMORY, POSTMEMORY AND THE ROLE OF NARRATIVES AMONG WOMEN WRITERS FROM THE ADIVASI COMMUNITIES OF GOA
}

\author{
Cielo G. Festino ${ }^{1^{*}}$ \\ ${ }^{1}$ Universidade Paulista, São Paulo, SP, Brasil \\ Andréa Machado de Almeida Mattos ${ }^{2 * *}$ \\ ${ }^{2}$ Universidade Federal de Minas Gerais, Belo Horizonte, MG, Brasil
}

\begin{abstract}
:
The aim of this paper is to analyze the life narratives "Where have All the Songs and Rituals Gone?" (2019) by Mozinha Fernandes and "A Velip Writes Back" (2019) by Priyanka Velip, members of the Adivasi community of Goa, who consider themselves as the first inhabitants of this Indian state. These narratives have been published in the blog "Hanv Konn. Who am I? Researching the Self" organized by the late professor from the University of Goa, Alito Siqueira, whose aim is to give voice to this marginalized and silenced community. The analysis will be done in terms of the concepts of Postmemory (Hirsch, 1996, 1997, 2008), Trauma (Ginzburg, 2008; Balaev, 2008), Narrative (Bruner, 2002; Coracini, 2007), and Life-narratives (Smith \& Watson, 2010).
\end{abstract}

Keywords: Adivasis; postmemory; trauma; narratives; life narratives.

This paper is dedicated to the memory of Professor Alito Siqueira (1955-2019)

\footnotetext{
"Teaches English at Universidade Paulista, São Paulo, Brazil. She is a member of the project 'Thinking Goa: A Singular Archive in Portuguese (2015-2019)', funded by the São Paulo Research Foundation. She is co-editor, with Paul Melo e Castro, of A House of Many Mansions: Goan Literature in Portuguese. An Anthology of Original Essays, Short Stories and Poems (Under the Peepal Tree, 2017), and, with Paul Melo e Castro, Hélder Garmes, and Robert Newman, of 'Goans on the Move', a special issue of Interdisciplinary Journal of Portuguese Diaspora Studies 7 (2018). E-mail: cielofestino@gmail.com. ORCID: https://orcid.org/0000-0003-2862-0554.

${ }^{* *}$ Associate Professor of English and Applied Linguistics at the Federal University of Minas Gerais (UFMG), Faculty of Languages and Linguistics, in Belo Horizonte, Minas Gerais, Brazil. She is also a Productivity Researcher, Level Pq2, from CNPq - National Council for Scientific and Technological Development (Process n. 308243/2020-0). E-mail: andreamattos@ufmg.br.ORCID: https://orcid.org/0000-0003-3190-7329.
} 


\section{Introduction}

In a recent paper, Andréa Mattos and Érika Caetano (2018) have brought the concept of postmemory to the field of Language Teaching and Language Teacher Education. By extension, we assume that it can also be applied to the field of literary or narrative studies. The term was created by Marianne Hirsch (1996) for whom postmemory refers to "the experience of those who grow up dominated by narratives that preceded their birth" (662). The author, a descendant of immigrant Ukrainians and now based in the United States, discusses the concept in relation to the memories of the Holocaust. In this paper, we use the term to refer to the postmemories of the Adivasis from Goa - former Portuguese colony in India from 1510 to $1961^{1}$-, the also so-called Tribal communities who consider themselves the first inhabitants of this Indian state (cf. Pereira 2009, 1). India is said to have the biggest Adivasi population in the world after Africa (Velip, 2019). Adivasis have been historically marginalized and in Goa they are considered as being part of the Bahujan Samaj, which the Goan critic Parag Parobo (2015) has defined as "a conglomeration of low-caste people, more than a monolithic group" (3). According to Mozinha Fernandes (2020, 20), the Adivasis have been systematically Othered as, since colonial times, they have been considered to be communities that have remained loyal to their ancestral traditions and customs, living many times in isolated areas, away from mainstream culture. What should be taken into account, however, is that this attitude also has to do with the way in which they have been marginalized, as Fernandes states in her poem "Discrimination": "No more can I suffer this discrimination/ Just let me live like you." ${ }^{2}$ So much so that though the Indian Constitution in its article 342 recognizes three of the Adivasi communities of Goa, Gawdas, Kunbis and Velip as "Scheduled Tribes", as Fernandes goes on to add: "Tribes have been transformed into castes with the policy of reservation in India. While castes that are notified [in the Indian Constitution] are referred to as 'Scheduled Castes,' my community as a Scheduled Tribe, is often referred to as belonging to the Gawda caste" (9, our emphasis), thus being doubly discriminated. Nonetheless, as Fernandes proves in her thesis (cf. Gawda Women 17), it is the culture of the Adivasi, in particular women's dances, songs and way of dressing that are considered as being symbolical of Goa's cultural heritage.

The narrative "To Gawda or not to Gawda," by the Goan writer Favita Dias (2015), portrays in special the predicament of the members of many Gawdas, one of the Adivasi communities from Goa. In this narrative, Dias finds herself in an identity conflict: to identify herself with the Gawda community to which she belongs through her ancestry or not. This identity conflict resonates with the reflections made by Chimamanda Ngozie Adichie (2009) in her TED Talk on "The Danger of a Single Story." In this talk, Adichie discusses her own fluid identity as an African, saying she only started identifying as such when she arrived in the U.S.: 
I must say that before I went to the U.S. I didn't consciously identify as African. But in the U.S. whenever Africa came up people turned to me. Never mind that I knew nothing about places like Namibia. But I did come to embrace this new identity. And in many ways I think of myself now as African (Adichie).

Just as Adichie, Favita Dias also finds herself at a crossroads in terms of her identity. In the last paragraph of her narrative, she says sometimes she regrets having discovered her "tribal identity" as a Gawda, but recognizes it has turned her into someone new: "I wish I had not discovered my tribal identity and faced such a situation. But this fact has actually shaped me into something different. It has changed me into a new person. A person with a new set of questions that requires new answers" (Dias, "To Gawda").

As Lynn Mario Menezes de Souza and Walkyria Monte-Mór (2006) put it, being a citizen of a specific country, or, in this case, belonging to a specific community, "involves the understanding of which position/place a person occupies in society" (91). The authors further clarify: "where do they speak from? Why is this their place? How did they get there? Do they want to be there? Do they want to change it? Do they want to get out of it?" (91). In this sense, Favita Dias, like many other Gawdas, is anxious to discover her place in her community: "All I hope for is to get over this confusion and have a clear mind about what I want to do and where I want to place myself. I am also interested in knowing if there are others who face crises similar to mine" (Dias, "Foreword").

In this context, this paper will focus in particular on three narratives from two Adivasi communities of Goa, Velips and Gawdas, written by women scholars during a post-graduate Sociology course at the University of Goa under the guidance of Professor Alito Siqueira and published in the Blog "Hanv Konn. Who am I? Researching the Self." ${ }^{3}$ All the narratives ${ }^{4}$ in this blog will eventually be published in book form. In the Foreword to the blog, Favita Diaspoints out the importance of this publication:

Knowing at the age of nineteen that I belonged to a tribal community and accepting it even while knowing the consequences wouldn't have been possible without Hanv Konn and Ami Konn. Not only am I now proud to accept my tribal identity, but also, as a woman, I am more confident in taking decisions about my desires and dreams (Dias, "Foreword").

Besides, what this Blog also shows is that, as Dias also remarks, though Goa is considered as a state in which discrimination due to caste or gender is less pronounced, when compared to other parts of India, "if you belong to the discriminated side you cannot afford to make such statements" (Dias, "Foreword"). We contend that the best way these women authors have found to deal with discrimination was by publicly acknowledging their cultural identity instead of veiling it as their parents as well as members of the community at large had done in in the past. As Favita Dias goes on to say: 
Each story of Hanv Konn is more inspiring than the other. A unique aspect of this work is that these are life stories of the writers themselves. This makes it even more valuable. Every story highlights some kind of injury, whether due to caste discrimination, gender discrimination, class, language, family, etc. The stories have the capability of touching the reader's deep-rooted and hidden feelings of pain. And they are more impactful because they come from those who have experienced the pain and have struggled with it (Dias, "Foreword").

Along the same lines, Siqueira (2019) observes that the Blog "Hanv Konn. Who Am I?" was created with the purpose of publishing these narratives so that they would reach a wider audience beyond the academic community and urge more people to pursue higher studies and tell their stories: "These authors show us how higher education could, and perhaps should, be a process of discovery and recovery from insults and hidden injuries while recreating one's identity as learners" ("Learning and Recovery").

In order to carry out this discussion, we will first consider the concept of narrative as discussed by Jerome Bruner $(1986 ; 2002)$, in particular the genres of testimony, as proposed by Jaime Ginzburg (2008), and life-narratives, according to Sidonie Smith and Julie Watson (2010), both of which have at their basis what Hirsch (2008; 2012) and Michelle Balaev (2008) define as intergenerational postmemory, to then analyze the narratives published in Hanv konn by Priyanka Velip (2019) and Mozinha Fernandes (2019).

\section{The Importance of Narrating}

As many other authors, Cielo Festino (2017) defends "the centrality and relevance of narratives" (89). For her,

There is no culture that does not need to hear and know the stories of its own experience and community. This propensity to narratives is due to the fact that, by imposing a certain order on the chaos of existence, they help man to make sense of his circumstances, shortening the distance between 'being' and 'knowing' (89).

Back in the last century, Jerome Bruner (1986) already advocated the importance of narratives. He described narratives as stories, myths, dramas and historical accounts that emphasize human intention and action, and which are "composed of a unique sequence of events, mental states, happenings involving human beings as characters or actors" (43). In another, more recent text, Bruner (2002) states that we listen to narratives and stories "endlessly, [...] and they seem almost as natural as language itself" (3). He contends that narratives and stories are present in our lives since a very early age and our connection with them lasts forever, turning narratives and stories into a way of thinking, a way of organizing and understanding our own experiences and those of others. Bruner also states that humans have an extraordinary "capacity to organize and communicate experience in a narrative form" (16) and that is what has made possible our 
collective life within a culture. For Bruner, it is through telling and listening to narratives and stories, including our own, that we construct an image of ourselves and gradually become who we are. In his perspective, narratives and stories not only report on facts and reality, but also construct reality as "narrative meanings impose themselves on the referents of presumably true stories" (9). In so doing, narratives and stories "shape our experience" and create Selves. As the author puts it, "we constantly construct and reconstruct ourselves to meet the needs of the situations we encounter, and we do so with the guidance of our memories of the past and our hopes and fears for the future" (64).

Vera Wielewicki (2017) and Festino agree that such narratives and stories are very much represented in literature in our modern society but may also be encountered in other forms of storytelling. Wielewicki says that "telling and listening to stories in different forms from those printed in books has been part of humanity for a long time" (77) and that, as we tell stories and listen to others' stories, we elaborate on our human reality. For her, we "deal with our life experiences, we learn and we have fun with the stories of real or fictitious characters, which mimic situations in which we are or could be involved" (77). Agreeing with Bruner, Wielewicki states that "narratives are fundamental to the construction of the individuals we are" (77).

Festino states that "the necessity to narrate $[\ldots]$ is vital for the individual and for the community" (99). Citing J. Edward Chamberlin (2004), she explains that the narratives belonging to "the different communities are as varied as the landscapes and the languages" and, according to her, "these narratives tell where people come from and why they are here; how to live and how to die" (90). These narratives may also have different formats: "from creation stories to the constitution of a nation, from the epics of the South to the Northern sagas, lullabies or national hymns, myths or mathematics" (90).

If, as Bruner (2002) explains, our narratives shape our experience and create our Selves, many times we need to create new stories in order to deal with our circumstances. These narratives associate aesthetics and ethics and each of them brings together different genres which are functional for the telling of the story, such as life-narratives, testimony, or even critical essays, among others.

Like the first Indian women writers, in order to narrate their stories, and that of their communities, some of these Tribal authors use an autobiographical style that Smith \& Watson define as life narratives: "acts of self-representation of all types and in different media that consider the life of the speaker as its main subject, whether in written, performative, visual, filmic or digital form" (4). In other words, the term "life narratives" refers to "autobiographical acts of any kind" (4). This style of autobiography is profoundly broad and democratic since it considers narratives of citizens who, historically, have been ignored as being of no value, as the classical autobiography focuses mainly on the lives of prominent characters of the community.

As for the testimony, Jaime Ginzburg explains that this kind of narrative, bent on deconstructing the official story by narrating the injuries and insults 
suffered by an individual or community, is in tension with a conflictive reality and gives voice to the excluded subaltern. Rather than being generalizing and homogenizing, the testimony is against official discourse and articulates specific cultural positions that go against any kind of authoritarian attitude. Ginzburg adds that the testimony is related to the experiences of a group of victims, of which the subject of the enunciation is its articulator. He also points out that, for the subject of the testimony, there can be an insurmountable chasm between the impact of the catastrophe suffered and the discursive resources available in order to articulate and tell the story; this is why, many times, the narrative might be inaccurate and insufficient. If this is true of many of the elder members of this community or those who did not have access to education, it does not apply to these Gawda women authors since their university studies have given them the tools so that, with affection and respect, they transcribe in written form the testimonies of the older members of the community.

Hence, their critical essays on the condition of their community is an instance of reflection not only for themselves, or for the Other who subjugates them, but also for the members of their community, who would rather keep silent, and for future generations. This has led them to try to change, through their writing, some of the fossilized attitudes of the Goan community, while striving to keep alive those customs which identify their community and which many times are hidden to avoid discrimination. As Alito Siqueira points out in the interview with Gaspar D'Souza: "So what are you asking me?...Wrong Question Mr. BBC,"5 these narrative styles - life narratives, testimony, critical essays - intersect three or four domains: the conservation of intangible heritage; the need of social justice as they aim at ressignifying the knowledge system of the community and rewrite the postmemory of suffering and discrimination inherited; pedagogical discourse as they point to the role learning plays to bring back to life the knowledge of the community which had been excluded; and cultural politics as they insufflate new life in the silenced stories of the culture.

Thus, rather than follow a process of Sanskritization, i.e., convert themselves to the values of the higher castes or classes, these women writers not only write narratives of awareness and resistance, but explicitly identify themselves as members of this class, the Adivasis. Precisely, in Abolim, Lucio Rodrigues (2015, 120) explains that, in Goa, surnames, in particular Hindu surnames, have been traditionally associated with places and communities. Then, with the coming of the Portuguese to India (1510-1961) and the massive conversion to Catholicism and change of names, "the new surnames like Colaço or Fernandes offered no clues to the status of the newly christened individual" (121). This called for a new strategy to place the individual. It is in this context, says Rodrigues, that the question in Konkani, “To Konna-Lo”, (121) was coined. The question literally translates as "Who are you?". However, more is implied in it. As Hindu family names are associated with the names of villages and, in turn, villages are associated with different social groups, asking for a person's surname helps place the person's origin within the local social hierarchy and the caste system. Nowadays, these young women authors are 
challenging the narrative implied in this question with a new one: "Hanv Konn?" [Who am I?] as, little by little, these communities are coming to the forefront and through their writings, which help them reconsider the postmemories inherited from their ancestors in a new light, they not only contest the different ways in which discrimination takes place but also, proudly, acknowledge themselves as members of their own communities and, in so doing, create new narratives which help redefine their own identities and their place in society (Dias 2019). ${ }^{6}$

\section{Postmemory and Narratives}

As stated in the introduction to this paper, the concept of postmemory was first used by Marianne Hirsch to "describe the relationship of the second generation with powerful, often traumatic, experiences that preceded their births but were nevertheless transmitted to them so deeply as to seem to constitute memories in their own right" ("The Generation of Postmemory" 103). In a later work, Hirsch (2012) defines postmemory as:

...the relationship that the "generation after" bears to the personal, collective, and cultural trauma of those who came before - to experiences they "remember" only by means of the stories, images, and behaviors among which they grew up. But these experiences were transmitted to them so deeply and affectively as to seem to constitute memories in their own right (Postmemory 5).

As Hirsch further explains, "postmemory's connection to the past is thus actually mediated not by recall, but by imaginative investment, projection and creation" (Postmemory 5). She adds that "these events happened in the past, but their effects continue into the present" (Postmemory 5). The concept is now being used by a number of researchers around the world in various disciplines to understand the impacts of memory on our identity and on our lives and on ways of seeing and being in the world, as well as how we position and articulate ourselves or make sense of our place and role in society (cf. Mattos \& Caetano).

Postmemory, as Hirsch (1997) first put it, "characterizes the experience of those who grow up dominated by narratives that preceded their birth, whose own belated stories are evacuated by the stories of the previous generation shaped by traumatic events that can be neither understood nor recreated" (Family Frames 22). These narratives, which belong to the previous generation, and are shaped by traumatic events that are passed on to the second generation by their ancestors - usually family members who have survived such events - inhabit both their minds and their identities. The author explains that this transmission of a memory passed on to those who did not experience the facts, but have learned about them through the stories of others, may also be a form of experience. For Hirsch, this is why postmemory "reflects an uneasy oscillation between continuity and rupture. [...] a structure of inter- and transgenerational transmission of traumatic knowledge and experience" ("The Generation of Postmemory" 106). 
In Family Frames, Hirsch's first book on postmemory, the author explains that "postmemory is distinguished from memory by generational distance and from history by deep personal connection" (22), that is, postmemory is neither memory nor history. In her view, the "second generation" has an intense relationship with the experiences of those who came before them and suffered collective trauma, "experiences that they 'remember' only by means of the stories, images and behaviors among which they grew" ("The Generation of Postmemory" 106). Postmemory, in this sense, is indirectly formed by traumatic historical events that happened in the past, but which still produce effects in the present.

Vitalina Araújo and Claudio Gonçalves (2012) say that "it is common for the victims of traumatic events [...] to carry in their memories unspeakable experiences of those who lived under the sign of pain, to bear in their countenance suffering, a consequence of the experience of those who were on the brink of death" (52). These victims, through stories and narratives, share their memories with the following generations. According to Araújo \& Gonçalves, this means "to recall/connect the rememberings of previous generations in a process of memory connection" (53).

It seems that interest in the concept of postmemory, and other similar concepts, is growing all over the world. Maria José Coracini $(2007,9)$ uses the concept of discursive memory to talk about "archive, memory and identity" and several other researchers have used the term "collective memory" (Halbwachs 2006) in a similar sense. Juan Almeida (2017) uses the concept of cultural memory to refer to Hirsch's concept of postmemory. As he contends, "memory is situated in a real conflict between remembering and forgetting" (10).

Silvio Jorge and Margarida Ribeiro (2013), in their introduction to the special issue of the journal Abril on memory and postmemory, state that "it is fundamental to use memory as a way of confronting and problematizing the political and historical trajectory" (10) of countries that have endured traumatic historical events. The authors highlight the importance of remembering for the several cultures, but also for the constitution of identity traces, which grant the group a sense of belonging. They also assert that the concept of postmemory may be an "instrument for the analysis of memory transmission to a second generation $[\ldots]$ creating a possible dialogue with a memory that, being alien, invades theirs, through family life, in order to crease its presence" (10).

Along the same lines, in "Trends in Literary Trauma Theory," Balaev discusses trauma as “...a person's emotional response to an overwhelming event that disrupts previous ideas of an individual's sense of self and the standards by which one evaluates that society" (150). In turn, the literature that is written on these events first conveys "profound loss or intense fear at an individual or collective levels" and then dramatizes "the transformation of the self-ignited by an external and terrifying experience, which illuminates the process of coming to terms with the dynamics of memory that inform the new perception of self and the world" (150). Likewise, Balaev adds that the concept of trauma is "timeless, repetitious and infectious" (152) in the sense that "a trauma experienced by a 
group in the historical past can be experienced by an individual living centuries later who shares a similar attribute of the historical group, such as sharing the same race, religion, nationality or gender" (152) and, many times, leading to the creation of racialized identities. According to these authors and, as we will try to show in this paper, through the study of the narratives in the Hanv Konn blog, the second generation, i.e., the one which receives the effects of postmemory, also suffers the consequences of trauma and loss.

\section{The Adivasis of Goa}

According to Pereira and Fernandes, the term tribe - after which the Adivasis are many times referred to as "Tribals" - is a very unstable category; it was imported into India by the British and later on adopted by the Portuguese during the colonial period. However, the word does not exist in Konkani or in Marathi, Goa's main local languages, or in the other Indian languages. Pereira further problematizes the term by pointing out its evolutionist connotations as it is used to refer to a society in an earlier stage of development. Even today, says Pereira, the members of the different Adivasi communities in Goa are many times associated with these colonial and linguistic assumptions.

In turn, the term tribe is related to the concept of caste. As explained by Unnithan-Kumar (1997), "caste and tribe are constructs and represent categories which are products of historical, contemporary, social, economic and political processes" (1). This is why, adds the critic, there is a fluid relationship between both. Regarding the different Adivasis of Goa, Pereira explains that, though socially they follow the caste organization, in administrative terms they are classified as a Scheduled Tribe - officially recognized Tribes by the Indian Government - for economic and educational benefits. Nonetheless, Pereira adds that, if many tribes were listed as castes during the colonial period, later on in the post-colonial period, those castes claimed their tribal status, as a sign of pride in their ancestry, as was the case of the Gawdas (cf. 55-56).

There are four Adivasi communities in Goa: Gawdas, Kunbis, Velips and Dhangars. While the first three have already been included in the Indian Constitution as Scheduled Tribes, the Dhangars are still demanding Tribal Status (Fernandes, Gawda Women, 11). They affirm to be the original inhabitants and first settlers of Goa who founded many of the villages of the state, which is synonymous with belonging to a tribal group (Pereira 2009). In some works, the word Gawda is used as an umbrella term that comprises all the other communities (Gune 1979; Gomes 2002; Braganza 2008; Velip 2019), while some communities would be a subgroup of others. In this paper, we will apply the terms - Gawdas, Kunbis - after the way they are used by each of the authors studied belonging to the different communities.

The word "Gawda" is translated in Konkani", the official language of the state of Goa, "as the one who establishes the village and administers it towards prosperity." According to Pereira, this community is at the basis of the social system which 
overtime split into three groups. Initially a Hindu community, the Gawda divided themselves when, with the coming of the Portuguese to India (1510-1961), some of them converted to Catholicism in order to avoid discrimination. Eventually, many of them reconverted to Hinduism (1928) when they realized that, though Catholics, they continued being discriminated against within the church. Those who reconverted are nowadays known as Neo-Hindus. Mozinha Fernandes adds that the members of this last group were then not accepted either by the Hindus or the Christians. According to Robert S. Newman (2019):

Whether Catholic or Hindu by affiliation, they share the same folk culture, and socio-economic position. Because of this, they may be said to have formed the solid base of traditional Goan regional culture: Konkanispeaking, having a common world view with mixed Catholic and Hindu elements, with a shared livelihood based on agriculture, fishing and liquor-distilling (60).

Nowadays, as Priyanka Velip affirms, narratives of inclusion rather than narratives of origin are of greater importance for the Adivasis: “Today it does not matter whether we are the original settlers of Goa or not, which is also debatable, but what we want is the inclusion of our own into the mainstream of society so that there are less chances of 'othering." And this is the thread that relates all the narratives studied in this paper.

The scope of the narratives in Hanv Konn is broad and covers different matters: the affirmation of identity, the process of being Othered, the recovery of the culture's traditions, displacement. What they all have in common is what has been defined as "intergenerational trauma" (Balaev 152) which, according to the author, "conflates the distinction between personal loss actually experienced by an individual, and a historical absence found in one's ancestral lineage". Personal loss can be defined as "the lived experience of an individual" (152) while "historical absence can be understood as a historically documented loss that was experienced by a person's ancestors" (152). Balaev adds that the theory of intergenerational trauma conflates loss and absence to the point of collapsing the limits between the individual and the group thus suggesting that "a person's contemporary identity can be vicariously traumatized" by their ancestors' experience (152).

It is the rewriting of the traumatic narratives of loss and absence of their communities that has empowered the authors, allowing them to recover their voices, often silenced by veiled or explicit forms of discrimination. At another level, as Newman suggests, what these authors are doing is offering an alternative view of the Goan community as a whole. Instead of looking at it from the perspective of the "Catholic, Western, and Portugal-oriented or Hindu, Indian and Maharashtra-oriented 'Big Tradition"' (p. 89), they consider it from the socalled "Little Tradition" (89) which, for mainstream culture, scarcely exists.

Through our analysis, we will try to show that for these women authors these narratives are spaces in which they move from being "[...] the object of observation" 
to "the subject of investigation, remembrance and contemplation" (Smith \& Watson 1), so that their stories can contribute to raising awareness among members of their communities and, eventually, improve their living conditions.

\section{Priyanka Velip and the Fear of Being Othered}

Mattos and Caetano explain that the concept of postmemory helps an individual or a community deal not only with his or their own identity and with their way of seeing and being in the world, but also with the way in which they make sense of their place and role in society. In "The Fear of Being Othered"10 (Velip), a life narrative and testimony of her own experience as a Velip, an Adivasi Hindu community, Priyanka Velip is bent on deconstructing the image, past and present, of her own people received from historians, who have recorded in written form the oral history of her culture: "To know more about my community-the Velip community in Goa- and how different writers have described my community, I read different works, and I feel that some of them contradict my experience. I also feel that I am being 'othered' through these writings" (Velip).

After a survey of some of the most important theoreticians on the cause of the Adivasis in Goa (Bezbaruah 2003; Bhandari 1999; Braganza 2008; Correia 2006; Gomes 2002; Gune 1979; Khedekar 2004; Phal 1982; Satoskar 1971; Sinai \& Ramkrishna 1985; Xavier 1993), she comes to the conclusion that rather than elucidating the status quo of her community, they are intent on marking their own superiority and, by extension, the inferiority of the culture under study: "If parents told their children to refer to those 'history' books, what impression would that child have regarding his own community? This is the imaginary question I have posed for my study. What then would be the fate of the future generations of Velips?" (Velip), For Priyanka Velip this helps explain why, though the Velips are considered among the original settlers of Goa and, therefore, have the first right to define themselves as "Goans," while their culture, ritual dress, define them as Goans, they still hide their Velip identity as well as their customs to the point that their community might lose its uniqueness.

As Velip goes on to explain, the problem lies in the way in which "the symbols of their identity" (Velip) have been historically used to Other their community. Their dances and even the way of tying the saree - the latter, paradoxically, a mark of Goan identity - have been used to "stigmatise the tribal communities" (Velip): while the Adivasi identity is used for the benefit of Goan tourism - Goa is a famous tourist destination in India and abroad ${ }^{11}$ - there is no real interest in the Velips or a desire to include them in the mainstream of Goan society.

As Hirsch observes, and Priyanka Velip's testimony attests, many communities grow up "dominated by narratives that precede their birth" (Family Frames 22), so much so that they prefer to deny them to the point of endangering their own cultural identity. This attitude explains, as Hirsch has also observed, "an uneasy oscillation between continuity and rupture [...] in the transgenerational 
transmission of knowledge and experience" ("The Generation of Postmemory" 106), a simultaneous process of recognition and denial. Priyanka Velip reflects:

What if after another twenty years a child of this changing community asks about our past - What kinds of customs, rituals, dress, food habits, etc. were there? By that time, we could possibly have lost our oral history and the last source would be only the books (Velip).

What worries Velip is that future generations of Velips might not have the chance to know the history of their community, or worse still, they might learn it from received postmemory narratives by historians and critics from outside their community, who explicitly or implicitly Other them, because, many times, the elders of their own community would rather ignore their own narratives as a way to fight against marginalization. The manner in which she, as well as many Adivasi women authors, has found to deal with this situation is by writing back; in other words, by deconstructing the intergenerational identity received through the creation of new narratives that might help future generations read their past from a different perspective: "Above all, understanding the concept of othering and inequality in literature has given birth to a new concept-'writing back'-a term applied to literary works that openly reflect upon their own processes of artful composition to deal with this problem of othering" (Velip). Such is the purpose of all the narratives in "Hanv Konn. Who am I? Researching the Self".

In the particular case of Priyanka Velip, her own narrative is an appeal to the members of her own community as well as Goans in general, to resignify the Velips' "culture, tradition, rituals and festivals regarded as entertainment or as instruments of leisure of joy" (Velip). This is so, Priyanka Velip adds, because many Velips "do not know the true knowledge behind them" (Velip): these songs and dances are the cultural reservoir of their own communities. As she concludes, "if we get this true knowledge about our culture and our tradition, then we will get true joy" (Velip). In turn, this new knowledge, acquired through these new narratives, written from within the fold of their community, will help them answer the question "Hanv Konn?" in Konkani, "Mi konn" in Marathi, "Who am I?" in English, foremost to better understand their place not only within their own culture but also as Goans and Indian citizens, now and in the future when, she fears, their cultural references might be lost if reduced to entertainment for tourists or object of study of foreign scholars:

I belong to the Velip community and am proud to be so because I know that even at the present time my community has a culture, traditions, festivals, and rituals, etc. that are unique. Today I feel proud, but my question is about the future: Will future generations of Velips be proud of being from this community? This is a most important question because, in the future, we Velips will have lost our uniqueness as it exists today, because we are on the track of losing our uniqueness already (Velip). 
Figure 1: The dance group of Kunbi women portrayal on the pamphlet "Cultural Heritage of Goa

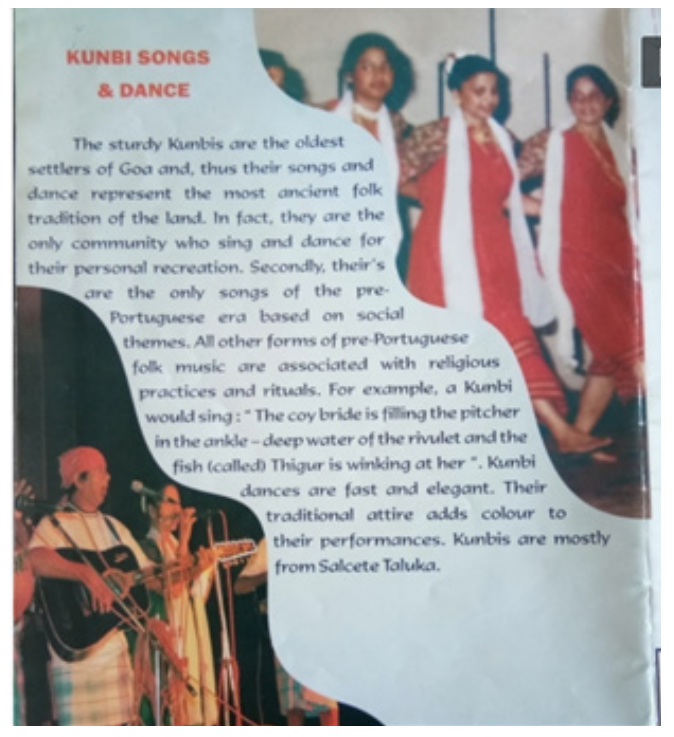

Source: Mozinha Fernandes, Gawda Women, 211

This pride in the uniqueness of their own customs and beliefs as well as the fear of losing them is related to the mixed feeling of, on the one hand, wanting to be part of the mainstream culture and, on the other, losing their cultural identity: "In one way this change is good, because when we say we are unique we are separating ourselves from togetherness. It may sound strange, but I am both proud and ashamed of being a Velip" (Velip). These same concerns are shared by Mozinha Fernandes, from the Gawda community, in her narrative "Where have all the Songs and Rituals Gone?” (2019).

\section{Mozinha Fernandes and the Recovery of Traditional Rituals and Songs}

In her narrative "Where have all the Songs and Rituals Gone?" 12 , Mozinha Fernandes associates three genres: life narratives, as she writes about her own community, the Gawdas; testimony, since, in order to discover why many traditional songs and dances have disappeared or are on the brink of disappearing, she interviewed many members of her community, and critical essay, as this genre gives her the necessary distance and breath to reflect on her own subject of analysis. If the first two genres help her relate aesthetics to ethics, the third one brings her discussion into the field of civil rights (cf. Ginzburg) and contributes to answering the research question which guides her work:

What do our people remember of their past, particularly of the ritual practices and songs that were performed until recently and why do some people want to forget them? [...] We identify ourselves by our name, our community, our religion, our ritual, our language, our music and our songs, and so on. All these are markers of our identity. But do we always identify ourselves with these markers? (Fernandes, "Songs and Rituals"). 
As discussed in the previous section, Halbawachs and Almeida use the term "collective memory" to refer to what Hirsch defines as "postmemory". This collective memory, like postmemory, is also situated at the crossroad between remembering and forgetting conflicting memories which cause pain or stigmatize a community. Fernandes contends that those who occupy a position of privilege in society feel proud of their past and the history of their community. Contrary to that, those who have suffered discrimination, as would be the case of the members of the Gawda community, at the hands of people of a higher caste, many times prefer to reject their own past:

I tried to ask the people I met: What do they think of their past? I went to Socobanda and began telling my friend Martha's grandmother that I needed her help in finding out details of the rituals followed by the Gawda community in the past. As I spoke, Martha's cousin came in, and Martha told him that I was doing a project on the Gawda people. The cousin interrupted her and said, "Hanv Gawddi num, Gawddi ti tumi." (I am not Gawddi, you are the Gawddis). He did not want to identify himself as a Gawda, but I could not understand why (Fernandes, "Songs and Rituals").

Therefore, when Fernandes interviewed people of her own community, in the Goan village of Ambelin, to learn about rituals and songs, many times they would be hesitant to speak about them. Fernandes both understood and knew from experience the conflict of the people she interviewed: if on the one hand the culture of the Gawdas had to be remembered and preserved, on the other hand, by sticking to it, they faced discrimination: "Remembering and forgetting are a part of human nature, but we do not forget things that are unique to us. Sadly, the Gawda people of Ambelim do not want to remember their past, and even if they remember it, they do not want to express their feelings about it" (Fernandes, "Songs and Rituals") as they many times manifested:

In my search for the songs of the past I asked two persons if they could remember and sing them. One man happily said, "Yes," but the other said, "Tem poilichem tuka kiteak zai? (Why do you want those old things?), I do not remember anything." [...] Even the aged vhoddil, (leader) Caitu Fernandes, rejected his past. I know that he knows many songs, as I have often seen him singing them. Once I had seen him singing when the Hayreache (fishermen) caste people came to Pedda. But he, too, refused, saying, "Zantelle ani kantaram mhonttat?" (Do old people sing songs?) (Fernandes, "Songs and Rituals").

In other cases, as also discussed by Priyanka Velip, several of the people Fernandes interviewed would replicate in their answers the received image that many of their songs and rituals represented an "uncivilized stage" of Goan culture and, therefore, they should be better forgotten: 
When I asked Javelin Fernandes why she thinks people have forgotten everything, she replied, "Atam soglem sudorlam" (Everything is changed and civilized). I asked her whether in the past people were not civilized. Her words were, "Poilim amkam sogllea von soklla mhonn lakttalim, punn atam soggllim ek" (In olden days we were considered as very low caste people in society, but today we are all equal) (Fernandes, "Songs and Rituals").

For some of the interviewees, denying their own past and symbols of identity, not only by performing jobs, like daily wage labourers, other than those allotted to their community - agriculture and cattle rearing - but also by changing their style of dressing, was the right path to follow in order to be treated on an equal basis, and be included in the mainstream of the culture:

According to [Javelin], today Gawda boys work on ships like the boys of other castes: 'Like Hayreache, caste people, our Gawda boys also go for fishing, and many have bought land like others. We have left our traditional dhentulli [traditional sari worn by Gawda women] and now we are wearing saris like others and we have become like them' (Fernandes, "Songs and Rituals").

Like Priyanka Velip, Mozinha Fernandes makes a point of showing that "History is an interpretation of the past, not the past as it really was" (Fernandes, "Songs and Rituals"). Therefore, in order to rewrite the history of her own community, she gives a thorough account of all the songs and rituals which have historically distinguished her community. For Newman, some communities, as would be the case of the Gawdas, derive "...important aspects of their identity and images of themselves and their past from festivals" (86). As Fernandes also contends, festivals are at the basis of the history of her community, guarded in the memory of her elders, and the best way to overcome the negative intergenerational postmemory associated with them is by rewriting them rather than reducing them to oblivion.

In one of her essays on postmemory, Hirsch speaks of a "sense of exile from a world [she has] never seen and never will see" ("Postmemory in Exile" 661) which is the city where her parents used to live before she was born, and where she cannot return to because it has been destroyed by the Holocaust. According to Hirsch, children of immigrants such as herself feel forever homeless, they "remain always marginal or exiled, always in the diaspora" ("Postmemory in Exile" 662). She adds that "postmemory is a powerful form of memory precisely because its connection to its object or source is mediated not through recollection but through an imaginative investment and creation" (662). That is, the second generation cannot really remember the places but try to fill in their memories with imagination and creativity, departing from their ancestors' stories. Hirsch concludes that "this condition of exile from the space of identity, this diasporic experience, is characteristic of postmemory" ("Postmemory in Exile" 662).

Likewise, as the Gawdas are a displaced community, and these same narratives, which Fernandes defines as "myth of origin," are associated precisely with their place of origin, they are very much cherished both by the elderly people 
even though they would keep them to themselves or talk about them only within their family circle, and the people of the new generation, like Fernandes, who have never been there. As Newman (86) explains, village origin can be as strong a source of bonding as religion or caste. Precisely, Fernandes would question her own parents about the origin of their family and community:

The Gawda people came to Ambelim from a place called Kazra. When asked where this place is situated the answer is up in the air; nobody knows where they actually came from, and the year is also not known. When I asked my parents to describe the place they told me that they travelled through thick forest and crossed waters to reach Kazra. People mostly used to go there during Carnival. I saw Kazra through my parents' eyes. It was a very noisy place, with much loud drumming, and many women dancing and running with big lighted divleo (lamps) on their heads. From very far you could see a monument of black stone. That's the description of the place, and nothing else was told to me by my parents (Fernandes, "Songs and Rituals").

Rather than a definite place of origin or the actual moment when her parents came to Goa, what Fernandes could visualize in a more concrete manner in her parents' narratives are the dancing and singing performed in Kazra. In general, they are life-cycle rituals that mark some of the most important events in the family life of a community: pregnancy, birth, marriage and death. They are also the rituals of the mandd, i.e, the sacred place of the community, where all the Gawdas used to meet to sing, dance and pray, before the Portuguese arrived and replaced it by the village square around the Catholic church. Not only that, but also many times they prohibited these same songs and dances in order to impose the Portuguese language and culture. As such, the Gawda's songs and dances constitute the history of the community. This is why Fernandes devoted herself to compiling these songs:

For marriage the women sang Erss (marriage songs); for sutti, performed on the seventh day after a child is born, they danced the fugddi and also sang songs; and for a death they sang religious songs. Songs were also sung on the sacred space of the mandd. Traditionally certain songs like mandd songs could be sung only by men, and the marriage songs were sung only by women (Fernandes, "Songs and Rituals").

Regarding the errs, marriage songs, according to one of the persons interviewed by Fernandes, nowadays many women refuse to sing errs at weddings because the singers are mocked by their own people, or because even the bride and bridegroom do not want to be associated with these traditional customs:

She told me of an incident in which two Gawda women sang Erss at one of the chapels of Ambelim. While they were returning after the event, two men from the other caste commented mockingly - "Avoie! Erss mhunnon ghelio!" (These mothers sang Erss and went off!). "That is why we do not like to sing," said Zina. "Forget about those Errs, the young Gawda couple who were about to marry said, "We do not want anyone to sing Erss for our marriage" (Fernandes, "Songs and Rituals"). 
As Fernandes concludes, many Gawda people are giving up their songs and rituals because they associate them with a painful history of discrimination which has been passed on from one generation to the next, to the point that this traumatic experience has been decisive in the identity formation of the community (Balaev):

I conclude that the Gawda people are dropping their own traditional customs and imitating the customs of others because they see this as being part of the process of becoming 'civilized.' By imitating the other castes, they have been able to compete with them in terms of acquiring land and money (Fernandes, "Songs and Rituals").

Fernandes, however, as the other authors in Hanv Konn, rather than affirming this received narrative of shame and repression, has written back not only by collecting and transcribing the songs and rituals of the community, in order to show their cultural and aesthetic value, but also by having them translated into a language of wider circulation so that they will reach a broader audience as the two errs below, translated into English by Salil Chaturvedi, ${ }^{13}$ attest:

\begin{tabular}{|l|l|}
\hline $\begin{array}{l}\text { Ponnos mhutto pikla } \\
\text { Pantiya phonda dampla } \\
\text { Sangat tuvem zodlam baba } \\
\text { Maiku visor naka } \\
\begin{array}{l}\text { Ani Maiku visor naka } \\
\text { (Sung to the bridegroom) }\end{array}\end{array}$ & $\begin{array}{l}\text { That jackfruit is ripe } \\
\text { It's covered with a basket } \\
\text { You have formed a new bond, boy } \\
\text { Don't forget your mother } \\
\text { No, don't forget your mother }\end{array}$ \\
\hline $\begin{array}{l}\text { Xiri Xiri valli } \\
\text { Fulloliya mirsanghi } \\
\text { Maiye besanv ditam baie } \\
\begin{array}{l}\text { Dimmi tuvu ghali } \\
\text { Ani dimmi tuvu ghali } \\
\text { (Sung to the bride) }\end{array}\end{array}$ & $\begin{array}{l}\text { The vine is so beautiful } \\
\text { The flowers bloom on the chilli } \\
\text { The mother showers her daughter with blessings } \\
\text { Kneel down to receive them, girl }\end{array}$ \\
\hline
\end{tabular}

Figure 2: Gawda women group for carnival float in Margao.

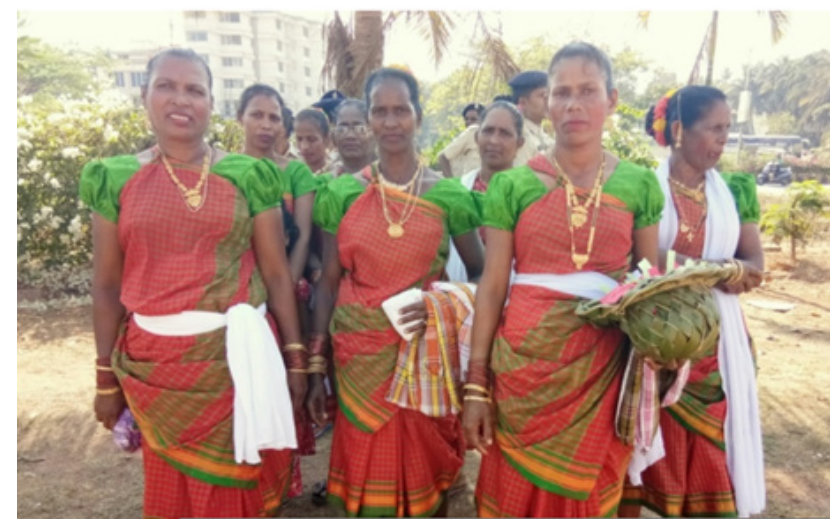

Source: Mozinha Fernandes $(2020,215)$. 
These errs, like other folklore songs, are autobiographical because they show how a community sees itself. As folklore reveals the areas of concern of the people, many times these narratives become a socially sanctioned outlet for wishes or anxieties individuals would not be able to express in their ordinary lives, like a mother's fear that now that her son is getting married he might forget her, as expressed in the err sung to the bridegroom, or a mother's blessing her daughter in the day of her marriage, in particular because, as it is the custom in India, brides move into the conjugal home leaving the natal home behind, as in the err sung to the bride. Folkloric narratives can then be understood as the system of knowledge of a community because they convey their values. At a formal level, this means that, as they are shared by all the members of the community, only the minimum information needs to be supplied, a fact which might account for the, at times, encrypted form of the narrative that juxtaposes images from nature to domestic ones, as in the errs above.

According to Ginzburg (63), in the elders' testimonies there might be a great distance between the narrative resources available to them and the story they are trying to tell. However, the refined verses of these marriage errs reveal the Gawda's dexterity in the composition of oral narratives which accompany each of the important celebrations of the culture. Besides, if, as already seen, the Gawdas are a displaced community that came from some place named Kazra, more than existing on maps, it lives on in the memory of the elderly members of the community, who reinvent it through successive rounds of retelling (Fernandes, "Songs and Rituals"). In so doing, they shape the identities not only of those who have actually experienced them but also of those who, like Mozinha Fernandes, are vicariously acquainted with them through the stories of their ancestors.

\section{Final Words}

As we have argued in this paper, the narratives by Dias, Fernandes and Velip helped them come to terms with their own cultural identities in spite of the way they have many times been marginalized, thus showing the power of reflection and healing which narratives have. In their effort to define themselves not in terms of the question "Where do you come from?" but "Who am I?", they not only reconnected themselves with the customs and beliefs of their own communities but also re-signified them since, rather than understanding them as marks of discrimination that had to be veiled or forgotten, they came to consider them as the true marks of their culture which had helped their ancestors survive and remain together through generations, and help present generations to proudly re-define their own cultural identity.

What helped them in this endeavor was the opportunity to have access to higher education and thus have the chance to see their own communities in perspective. As Alito Siqueira observes in Hanv Konn (2019), education and, by extension, becoming the author of one's own narratives instead of being forever the object of another's discourse has the double purpose of recovery and discovery. 
This involves an active process not only of remembering definite past events or blindly reproducing the customs and rites of a time gone by, but a process of selection, interpretation and reconstruction of the memories of one's ancestors in order to keep the past of the community alive, as well as help future generations to insert themselves in the mainstream life of the country.

As a tribute to Alito Siqueira, we would like to close this paper with his own words on the importance of inclusion, education and on being the narrator of one's own narratives:

Much more needs to be done in terms of what is taught and how it is taught, but that is likely to happen only when those who are the victims of the system have an opportunity to change the system. Hence the need to fight for inclusion wherever and whenever it is possible (Siqueira, Where Does the Tiger Live?).

Notes

1. Goa was a Portuguese colony from 1510 to 1961 when it was integrated into India. During its four-hundred-year presence in Goa, Portuguese colonialism materialized in its policy of mass conversion to Catholicism and integration that ended up producing a new society. This new society was marked not only by a Portuguese-speaking Catholic gentry, but also by other communities becoming Catholic and Lusitanianised to varying degrees, as groups of the Adivasi community converting to Catholicism attests.

2. https://hanvkonn.wordpress.com/2019/08/02/where-have-all-the-songs-andrituals-gone/\#more-357. Accessed on April 18, 2021.

3. https://hanvkonn.wordpress.com/. Accessed on February 24, 2020.

4. The other narratives in the blog are: "Why Dance?" by Elizabeth Bara; "Remembering the Past: Place and Memory after Displacement" by Venisha Fernandes; "Ashamed of Speaking in Konkani" by Avita Goansalves; "The Women Vendors at the Mapusa Friday Market" by Cheryl de Souza; "Religion and Identity in Transition" by Rejeshwari Mesta; "My Ancestral Home: Where is It"? by Preeti Padgaonkar; "Higher Education among Muslim Girls" by Khushboo I. Narangi; "Negotiating Male Migration: The Experience of Women in Goa" by Sachin Savio Moraes.

5. Available at www.facebook.com/story.php. Accessed on February $24^{\text {th }}, 2020$.

6. Available at https://hanvkonn.wordpress.com/2019/08/02/foreword/\#more-88. Accessed on 7 Aug. 2019.

7. Available at http://periodicos.uff.br/revistaabril. Accessed on November $3^{\text {rd }}, 2018$.

8. The main languages of Goa are Konkani, Marathi, Portuguese and English.

9. Available at http://mandogoa.blogspot.com.br/2008/02/our-point-of-viewtribal-voices-from.html; Accessed on May 2 ${ }^{\text {nd }}, 2019$.

10. A Velip Writes Back, Priyanka Velip. 2010. An edited version of the master's dissertation project at the Department of Sociology, Goa University. The work is licensed under the Creative Commons, copyright with individual author. Creative Commons Attribution-Non-Commercial 4.0 International License.

11. See Claudia Pereira, "Religious Dances and Tourism: Perceptions of the 'Tribal' as the Repository of the Traditional in Goa, India". In Etnográfica, v. 21, n. 1, February 2017, pp. 12-152. 
12. Where Have All the Songs and Rituals Gone? Mozinha Fernandes. 2019. An edited version of the master's dissertation project at the Department of Sociology, Goa University. The work is licensed under the Creative Commons, copyright with individual author. Creative Commons Attribution-Non-Commercial 4.0 International License.

13. Salil Chaturvedi is a writer and poet based in Goa. His short fiction and poetry have appeared in numerous journals, including Wasafiri, Guftugu, João Roque Literary Journal and Indian Quarterly. He is the Asia-region winner of the Commonwealth Short Story Competition, 2008, and he also won the Unisun/ British Council Short Story Award in 2009. He also won the Wordweavers Poetry Contest in 2015. His debut poetry collection titled, In The Sanctuary Of A Poem, was released at the Goa Arts and Literature Festival, 2017.

\section{Works Cited}

Adichie, C. N. TEDtalksDirector. "The Danger of a Single Story | Chimamanda Ngozi Adichie." YouTube, YouTube, 7 Oct. 2009, www.youtube.com/ watch?v=D9Ihs241zeg. Accessed 21 Oct. 2009.

Almeida, J. de A. "Memória, universidade, cidadania e Constituição na era das Comissões da Verdade: elucubrações comparativas a partir da vida e obra da Família Kucinski." Simpósio Nacional de História XXIX: Vigésimo Nono Simpósio Nacional de História - contra os preconceitos: história e democracia, July 24-28, 2017. Brasília - DF, http://www.snh2017.anpuh.org/resources/anais/54/1489624814_ ARQUIVO_STANPUH2017.pdf. Accessed 16 Sept. 2017.

Araújo, V. R. de; Gonçalves, C. de C. "Em estado de memória: experiência, memória e pós-memória no relato de Tununa Mercado." Litterata: Revista do Centro de Estudos Portugueses Hélio Simões, vol. 2, no. 2, 2012, pp. 51-70, http://periodicos. uesc.br/index.php/litterata/article/viewFile/602/593. Accessed 3 Nov. 2018.

Balaev, M. “Trends in Literary Trauma Theory." Mosaic: An Interdisciplinary Critical Journal, vol. 41, no. 2, 2008, pp. 149-166, https://www.jstor.org/stable/44029500. Accessed 2 Mar. 2020.

Bezbaruah, M. P. Fairs and Festivals of India. Vol-IV. New Delhi: Gyan Publishing House, 2003.

Bhandari, R. Goa. New Delhi: Roli Books Pvt Ltd, 1999.

Braganza, M. S. R. Statements by GAKUVED and Rama Velip of Colomb, 2008, http:// www.mail-archive.com/goan-nri@yahoogroups.co.in/msg03419.html. Accessed 5 Aug. 2009.

Bruner, J. Actual Minds, Possible Worlds. Cambridge, MA: Harvard University Press, 1986.

Bruner, J. Making Stories: Law, Literature, Life. Cambridge, Mass: Harvard University Press, 2002.

Chamberlin, E. J. If This is Your Land, Where are Your Stories? Toronto: Random House, 2004.

Coracini, M. J. A celebração do outro: arquivo, memória e identidade. São Paulo/ Campinas: Mercado de Letras, 2007.

Correia, L. de A. Goa: Through the Mists of History from 10,000 BC-AD 1958. Panjim. Maureen Publishers Pvt Ltd, 2006.

Dias, F. "To Gawda or not to Gawda." 2015, http://www.dalitweb.org/?p=2963. Accessed 13 April 2020. 
Dias, F. "Foreword." 2019, https://hanvkonn.wordpress.com/2019/06/09/foreword/. Accessed 13 April 2020

Fernandes, M. "Where have all the Songs and Rituals Gone?" 2019, https:// hanvkonn.wordpress.com/2019/08/02/where-have-all-the-songs-and-ritualsgone/\#more-357. Accessed 24 Feb. 2020.

Fernandes, M. Christian Gawda Women. Culture and Imagining Goa. PhD Thesis. Goa University, 2020.

Festino, C. G. "Os avanços tecnológicos: o fim da literatura?" Takaki, N. H.; Maciel, R. M. (Orgs.). Letramentos em terra de Paulo Freire. 3 ed. (ampliada), Campinas, SP: Editora Pontes, 2017. pp. 89-100.

Ginzburg, J. "Linguagem e trauma na escrita do testemunho." Conexão Letras, vol. 3, no. 3, Porto Alegre, 2008, pp. 61-68.

Gomes, O. Goa. New Delhi: National Book Trust, 2002.

Gune, T. Gazetter of the Unionn Territory of Goa, Daman and Diu: Panaji: Government of Goa, Daman and Diu, 1979.

Hirsch, M. "Past Lives: Postmemories in Exile." Poetics Today, vol. 17, no. 4, Creativity and Exile: European/American Perspectives II (Winter), 1996, pp. 659-686, https://doi.org/10.2307/1773218. Accessed 19 Jan. 2017.

Hirsch, M. Family Frames: Photography, Narrative, and Postmemory. New York: Harvard University Press, 1997.

Hirsch, M. “The Generation of Postmemory." Poetics Today, vol. 29, no. 1, 2008, pp. 103-128.

Hirsch, M. The Generation of Postmemory: Writing and Visual Culture after the Holocaust. Nova York: Columbia, 2012.

Halbwachs, M. A memória coletiva. Trad. de Beatriz Sidou. São Paulo: Centauro, 2006.

Jorge, S. R.; Ribeiro, M. C. Apresentação. Revista Abril, vol. 5, no. 11, 2013, pp. 9-12, http://www.revistaabril.uff.br/index.php/revistaabril/article/view/41/35. Accessed 3 Nov. 2018.

Khedekar, V. V. Goa Kulmi. Goa: Mahesh Angle, 2004.

Mattos, A. M. A.; Caetano, "E. A. Memory, postmemory and critical language teacher" education. Analecta Politica, vol. 8, no. 15, 2018, pp. 239-258. D.O.I.: http://dx.doi.org/10.18566/apolit.v8n15.a04.

Menezes de Souza, L. M. T.; Monte Mór, W. Orientações curriculares para o ensino médio: linguagens, códigos e suas tecnologias - conhecimentos de línguas estrangeiras. Brasília: Ministério da Educação / Secretaria de Educação Básica, 2006, http://portal.mec.gov.br/seb/arquivos/pdf/book_volume_01_internet.pdf. Accessed 6 Feb. 2008.

Newman, R. S. Goan Anthropology. Mothers, Miracles and Mythologies. Saligão, Goa: Goa 1556, 2019.

Parobo, P. India's First Democratic Revolution - Dayanand Bandodkar and the Rise of the Bahujan in Goa. New Delhi: Penguin, 2015.

Pereira, C. Casta, tribo e conversão. Os Gauddes de Goa. Tese de doutorado. Lisboa. ISCTE-IUL, Outubro, 2009.

Phal, S. R. Society in Goa. Delhi: R.B. Publishing Corporation, 1982.

Rodrigues, L. Abolim. The Flower Songs, Folk Tales and Legends of Goa. Saligão, Goa: Goa 1556, 2015. 
Satoskar, B. D. Gomantak: Prakriti ani Sanskriti. Pune: Shubdha,Saraswati, 1971.

Sinai, D.; Ramkrishna, A. The Cultural History of Goa: From 10,000 BC-1352 AD. Panaji: Ramesh Anant S. Dhume, 1985.

Siqueira, A. "Learning and Recovery are Messy and Emotional." 2019, https://hanvkonn. wordpress.com/2019/06/09/whats-in-this-blog/. Accessed 18 Feb. 2020.

Siqueira, A. Where does the Tiger Live? Reservation. Vs Inclusion. 2019, https:// hanvkonn.wordpress.com/2019/09/05/where-does-the-tiger-live-reservation-vsinclusion/\#more-538. Accessed 11 April 2020.

Smith, S.; Watson, J. A Guide for Interpreting Life Narratives. Reading Autobiography. London \& Minneapolis: University of Minnesota Press, [2001] 2010.

Unnithan-Kumar, M. Identity, Gender and Poverty. New Perspectives on Caste and Tribe in Rajasthan. Providence e Oxford: Berghahn Books, 1997.

Velip, P. A Velip Writes Back, 2019, hanvkonn.wordpress.com/2019/08/09/a-velipwrites-back/. Accessed on Feb. 19th, 2020.

Wielewicki, V. H. G. "Narrativas multimodais e possibilidades para uma educação pluralista." In: Takaki, N. H.; Maciel, R. M. (Orgs.). Letramentos em terra de Paulo Freire. 3rd ed. (ampliada), Campinas, SP: Editora Pontes, 2017, pp. 77-88.

Xavier, P. D. Goa: A Social History. Panaji: Rajhauns offset, 1993.

Recebido em: 22/11/2020

Aceito em: $14 / 04 / 2021$ 